\title{
The Impact of Working Capital Management on Financial Performance: Evidence from Jordan
}

\author{
Mohammad Abdullah Fayad Altawalbeh \\ Accounting department, business faculty, Tafila Technical University, Jordan, E-mail: Tawalbeh@ttu.edu.jo
}

\begin{abstract}
The aim of this paper is to investigate the impact of working capital management on profitability. Working capital management was measured using; average collection period, average age of inventory, average payable period and cash conversion cycle as a comprehensive measure of working capital management. Two measures of profitability were employed; return on assets and net profit margin. The sample consisted of 33 industrial companies listed on Amman stock exchange (ASE) for the period from 2013-2017. Data required was gathered manually through the annual reports publicly available on (ASE). Panel data methodology was used with eight multiple regressions to test the study hypotheses. The findings revealed that average collection period and average age of inventory have a negative and significant impact on profitability measures; this implies that managers can enhance profitability by keeping average collection period and average age on inventory at the reasonable minimum level. However, the findings found no impact of cash conversion cycle on the net profit margin. This study contributes to the literature by providing recent evidence from developing countries about the impact of working capital management on profitability.

Key words Working Capital Management, Cash Conversion Cycle, Profitability, Net Profit Margin, Return on Assets

Received: 10 Apr $2020 \quad$ (C) The Authors 2020

Revised: 03 May 2020 Published by Human Resource Management Academic Research Society (www.hrmars.com)

Accepted: 10 May 2020 This article is published under the Creative Commons Attribution (CC BY 4.0) license. Anyone may Published Online: 14 May 2020 reproduce, distribute, translate and create derivative works of this article (for both commercial and non-commercial purposes), subject to full attribution to the original publication and authors. The full terms of this license may be seen at: http://creativecommons.org/licences/by/4.0/legalcode
\end{abstract}

\section{Introduction}

Working capital management is defined as a series of decisions regulating the use of short term assets and liabilities in the company in terms of investment levels and uses of them in a manner that strikes a balance between liquidity management and the level of profitability (Deloof, 2003), the main idea of working capital management is to achieve The balance between two important elements, the first is to maintain an adequate level of liquid assets to meet the risks of financial hardship, and the other is to invest in less liquid assets to achieve a satisfactory return.

Working capital management is a critical component of corporate success due to its direct impact on both the objectives of liquidity and profitability, as such, management seeks to touch the optimal level of working capital, management's commitment to conservative policy in working capital management requires maintaining a high level of current assets Which will reduce liquidity risk and enhance the company's ability to meet operational requirements, but at the same time it will reduce profitability and cause lost investment opportunities and high opportunity costs. In contrast, management pursues an aggressive policy in managing working capital that requires maintaining a low level of current assets with the aim of achieving a high level of profitability encounters high liquidity risk (Afza \& Nazir, 2010). Thus, the role of efficient management of working capital includes managing current assets and liabilities, so that to achieve a balance between moving away from liquidity risk on the one hand and achieving optimal 
utilization of the current assets on the other hand, more specifically, the efficiency of the financial manager in managing inventory, receivables and payables is considered an influencing factor in maximizing the market value of companies. The low level of capital invested in inventory and debtors will lead to inability to carry out daily operational requirements, which will lead to low sales and thus lower profitability, this may ultimately affect the going concern of the company (Filbeck \& Krueger, 2005). Management success in managing working capital depends upon understanding the nature of the interaction between current assets and traded liabilities, which may be influenced by several factors, including the nature of the industry, the conditions for supply of raw materials and the availability of financing (Boopathi \& Leeson, 2016).

In Jordan, the industrial sector is an important part of the Jordanian investment environment, and in light of the dynamic economy, the business environment is characterized by large levels of uncertainty, which may negatively affect the continuity of companies, and it is worth mentioning that a large part of the time of financial managers is consumed in following up on the daily operations that Related to working capital management In pursuit of optimal utilization of assets in a manner that does not negatively affect the liquidity of the company, The financial manager can achieve this balance by understanding the nature of the relationship between the components of working capital on the one hand and its impact on the performance of companies on the other hand, which will have the greatest impact in providing appropriate levels of profitability and thus maximizing the wealth of shareholders.

\section{Literature review}

Working capital management receives much debate and continues to attract scholar attention due to its pivotal role in serving and steering operational efficiency, however, there is no consensus about the impact of working capital management on financial performance (Kasozi, 2017). Each business is in need for working capital to carry out day-to-day operations which is essential for going concern. Decisions regarding current assets and current liabilities affects liquidity and investments return (Vashnani \& Shah, 2007), in the worst case, business may face bankruptcy as a result of poor planning of working capital components (Kargar \& Bluemethal, 1994). Deloof (2003) argued that managers may enhance the firm's profitability by obtaining optimal level of working capital components, keeping high level of inventory reduces stock-out risk, and even enables firms to adopt generous credit policies which leads to higher sales. Using a sample of 1009 of large Belgian firms, (Deloof,2003) investigated the relationship between WCM and profitability the researcher employed the number of days accounts receivables, the number of days inventory, and the number of days accounts payable to measure trading and inventory policies, the researcher concluded that managers can enhance profitability by reducing number of days accounts receivables and inventory, the study also concluded that less profitable firms take longer time to settle their accounts payable.

Lazaridis \&Tryfondis (2006) used a sample of 131 firms listed on Athens stock exchange in order to examine the relationship between WCM and gross profit; they concluded that managers can enhance profit through keeping working capital at the optimal level. Gill et al. (2010) extended the findings of (Lazaridis \& Tryfondis, 2006) using a sample of 88 American firms, they concluded that managers can enhance profit by reducing average collection period of receivables, However, average days of accounts payables and inventory have a very poor impact on profitability. Rehman \& Nasr (2007) examined the role of working capital management on enhancing profitability using a sample of 94 Pakistani firms; they concluded that managers can improve profitability by reducing the cash conversion cycle. Malik \& Bukari (2014) replicated Rehman \& Nasr (2007) by using a sample of 38 Pakistani firms from chemical and cement sectors, average days of inventory, receivables, payables and cash conversion cycle were used to measure working capital management, the researchers concluded that firm's performance is negatively associated with cash conversion cycle. In the same context, Mohammad et al. (2012) conducted an analysis of 25 Pakistani textile firms to find out the association between working capital management and firm's profitability, they used the absolute value of receivables, payables and inventory to measure working capital management, the results revealed a positive relationship between inventory value, receivables and profitability.

In an attempt to investigate the relationship between working capital management firm's value, Alavinasab \& Davoudi (2013) used a sample of 147 firms listed on Tehran stock exchange; they found that 
firm's value is negatively related to the length of cash conversion cycle and debt ratio. In Turkey, (Vural et al., 2012) examined the effect of working capital management on firms' performance, Using 75 industrial firms listed in bursa Istanbul, the researchers concluded that cash conversion cycle and average days accounts receivables have a negative impact on Tobin-Q and gross profit, while average days accounts payable have no impact on performance. In Singapore, Mansoori \& Mohammad (2012) analyzed pooled date of 92 firms; they revealed an important role of working capital management in enhancing the firm value. Napompech (2012) examined the impact of working capital management on firm's value, the sample consisted of 255 of Thai listed firms, working capital management was measured using cash conversion cycle, average days in inventory, average days accounts receivables and average days accounts payable. He concluded that average days in inventory, cash conversion cycle and average day's accounts receivable have a negative impact on gross profit, while the average day's accounts payable has a positive impact on gross profit. He suggested that managers can profitability by shortening the cash conversion cycle.

In Jordan, Abuzayed (2011) investigated the relationship between working capital management and profitability, the researcher used the gross operating profit as a dependent variable to stands for profitability. Cash conversion cycle, average days in inventory, average collection period and average repayment period were used to measure working capital management the results revealed a negative relationship of average collection period, average days in inventory and positive relationship of average day's accounts payable with profitability. The researcher concluded that keeping minimum inventory and reducing the collection period length along with extending the payment period enhance profitability. In the same context, Kaddumi \& Ramadan (2012) replicated Abuzayed (2011) using a sample of 49 industrial companies listed on Amman Stock Exchange for the period of 2004-2009. The researchers reported a negative relationship between performances on the one hand and the average collection period and the cash conversion cycle on the other hand, in addition, the results revealed poor relationship between performance, average repayment period and the average days in inventory. In summary, previous studies provide no clear cut relationship between components of working capital management and performance even within the same business environment and industries.

The efficient management of working capital components is vital to the companies going concern. Decisions related to inventory management, receivable and payables are a critical element in companies' success (Filbck et al., 2005). The process of managing the elements of working capital requires a high degree of caution as it relates to managing assets and short-term liabilities, and efficient management requires striking a balance between avoiding idle working capital on one hand and avoiding the risks of the company being unable to meet its short-term obligations on the other hand, which is known as the tradeoff between profitability and liquidity (Mohamad et al., 2010), thus, the Study questions can be formulated as follows:

1. Is there a significant impact of working capital management on financial performance?

2. Is there a significant impact of average age of inventory on financial performance?

3. Is there a significant impact of the average collection period of receivables on financial performance?

4. Is there a significant impact of the average payment period of creditors on financial performance?

5. Is there a significant impact of the Cash conversion cycle on financial performance?

\section{Methodology of research}

\subsection{Data and Empirical models}

The data used in this study was collected manually through the firm's financial reports publicly available on (ASE) website, The study population consists of all manufacturing companies listed on (ASE) covering the period from 2013-2017. The study sample consists of 33 manufacturing companies from which data required is available throughout the study period. Working capital components are used as the determinant of profitability, the financial performance of companies will be measured through two measures, an accounting measure and a market measure, and therefore, two models will be used. The first one relates to measuring the impact of working capital management on performance measured by return on assets (ROA) and the second model will address measuring the impact of working capital management 
through the net profit margin (NPM), To obtain the net effect, a number of controlling variables will be used, which are the financial leverage, the size of the company in addition to the age of the company.

$\mathrm{ROA}=\mathrm{a}+\mathrm{B} 1(\mathrm{WCM})+\mathrm{B} 2$ size+B3leverage+B4 age

$\mathrm{NPM}=\mathrm{a}+\mathrm{B} 1(\mathrm{WCM})+\mathrm{B} 2$ size+B3 leverage+B4 age

*Each model will be modified to employ one component of WCM at a time.

*components of WCM are presented in table1.

\subsection{Study hypotheses}

$\mathrm{H} 1$ : There is statistically significant impact of working capital management on profitability measured by ROA.

H1-1: There is statistically significant impact of the average age of inventory on profitability measured by ROA.

H1-2: There is statistically significant impact of the average collection period on profitability measured by ROA. by ROA.

H1-3: There is statistically significant impact of the average payment period on profitability measured

H1-4: There is statistically significant impact of the cash conversion cycle on profitability measured by ROA.

$\mathrm{H} 2$ : There is statistically significant impact of working capital management on profitability measured by NPM.

$\mathrm{H} 2-1$ : There is statistically significant impact of the average age of inventory on profitability measured by NPM.

$\mathrm{H} 2-2$ : There is statistically significant impact of the average collection period on profitability measured by NPM.

H-2-3: There is statistically significant impact of the average payment period on profitability measured by NPM.

$\mathrm{H} 2-4$ : There is statistically significant impact of the cash conversion cycle on profitability measured by NPM.

\subsection{Measurement of variables}

Following (Gill et al., 2010; Namompech, 2012; Jayurathne, 2014; Naveed et al., 2014; Mansoori et al., 2012; Deelof, 2003; Malik et al., 2014) The cash conversion cycle and its components were used to measure working capital management, the cash conversion cycle represents the time lag between cash outlay and cash recovery. Average collection period is the time it takes a company to collect its accounts receivable, which is considered an acceptable measure of receivables 'liquidity and the credit policy pursued by the company. Average Age of Inventory reflects the time required to convert inventory into goods and products. Average Payment Period represents the time it takes to pay off its current liabilities. Two measures of firms' performance are used; return on assets (ROA), and net profit margin (NPM) In line with previous studies, a number of control variables are included in the study regressions, I control for firms' size, leverage and firms' age. Table 1 below summarizes the study variables, measurement along with the predicted sign.

Table 1. Variables definition and measurement

\begin{tabular}{|c|c|c|c|}
\hline & Label & Measurement & Predicted sign \\
\hline \multicolumn{4}{|l|}{ Independent variables } \\
\hline Cash conversion cycle in days & $\mathrm{CCC}$ & $\begin{array}{l}\text { Average collection period+ Average Age of } \\
\text { Inventory- Average Payment Period }\end{array}$ & - \\
\hline Average collection period in days & ACP & (Accounts receivable $* 365$ )/sales & - \\
\hline Average Age of Inventory in days & AAl & (Inventories $* 365$ )/cost of sales & - \\
\hline Average Payment Period in days & APP & (Accounts payable $* 365$ )/net purchases. & + \\
\hline \multicolumn{4}{|l|}{ Dependent variables } \\
\hline Return on assets & ROA & $\begin{array}{l}\text { Profit before interest and tax divided by total } \\
\text { assets }\end{array}$ & \\
\hline
\end{tabular}




\begin{tabular}{lclc}
\hline & Label & \multicolumn{1}{c}{ Measurement } & Predicted sign \\
\hline $\begin{array}{l}\text { Net profit margin } \\
\begin{array}{l}\text { Control variables } \\
\text { Size }\end{array}\end{array}$ & NPM & Net profit divided by sales & + \\
leverage & Size & Natural log of Firm's total assets & - \\
Firm's age & LEV & Total liabilities divided by total assets & - \\
& age & $\begin{array}{l}\text { \# of years since the firm has been listed plus one } \\
\text { to avoid ages of zero }\end{array}$ & - \\
\hline
\end{tabular}

\section{Results and Discussions}

\subsection{Descriptive statistics}

Table 4 presents the descriptive statistics of the study variables; the length of cash conversion cycle is 64.37 days. The firms within the study sample take about 145.56 days to sell their inventory, but on average it takes 88.64 days to receive payment on their sales. On average the firms take 85.78 to pay their purchases. Minimum and maximum amounts of ROA are $(-43.79)$ and $(28.43)$ respectively and on average firms achieved (1.716) return on their assets, while the average of the net profit margin is (3.32).

Table 2. Descriptive Statistics

\begin{tabular}{|c|c|c|c|c|c|}
\hline Variables & Observation & Mean & Std. deviation & Minimum & Maximum \\
\hline $\mathrm{CCC}$ & 165 & 64.37 & 40.23 & -112.4 & 486.5 \\
\hline $\mathrm{ACP}$ & 165 & 88.646 & 78.37 & 20 & 747 \\
\hline AAI & 165 & 145.56 & 96.57 & 0 & 576 \\
\hline APP & 165 & 85.78 & 69.26 & 4 & 315 \\
\hline ROA & 165 & 1.716 & 7.61 & -43.79 & 28.43 \\
\hline NPM & 165 & 3.32 & 30.21 & -33.01 & 64.23 \\
\hline Size & 165 & 5.40 & 1.42 & .84 & 3.11 \\
\hline LEV & 165 & 3.48 & 19.8 & .40 & 99.8 \\
\hline Age & 165 & 31.3 & 16.8 & 4 & 66 \\
\hline
\end{tabular}

\subsection{Multicollinearity}

Table 2 presents the correlation matrix to investigate the existence of multicollinearity problem between the independent variables, this problem exists when two or more independent variables are strongly correlated (Alqatamin, 2018; Altawalbeh, 2020), Gujarati (2008) considers 80 percent to be the starting level of the multicollinearity problem, as such, the data set used in this study is free from multicollinearity problem as the highest correlation is between AAI and CCC with coefficient of $65.2 \%$ as presented in Table 2.

Table 3. Correlation matrix

\begin{tabular}{cccccccc}
\hline Variables & CCC & ACP & AAI & APP & SIZE & LEV & AGE \\
\hline CCC & 1.00 & & & & & & \\
ACP & -0.540 & 1.00 & & & & & \\
AAI & 0.652 & -0.004 & 1.00 & & & & \\
APP & -0.615 & -0.152 & 0.037 & 1.00 & & & \\
SIZE & 0.152 & 0.084 & 0.088 & -0.168 & 1.00 & 1.00 & \\
LEV & -0.014 & 0.031 & -0.001 & -0.002 & -0.021 & 0.022 & 1.00 \\
AGE & 0.211 & 0.151 & 0.0205 & -0.225 & 0.110 & 0.025 \\
\hline
\end{tabular}

\subsection{Regression analysis}

In this section I employed the fixed effects model to investigate the impact of WCM on profitability, fixed effects captures the effects of the independent variables over time (Deloof, 2003). Two measures of profitability were used; ROA and NPM. First, in regressions (1) to (4) ROA was used as a proxy of profitability, results are presented in table 3 , in regression (1) AAI was used as determinant of ROA, in regressions (2),(3) and (4) , ACP,APP and CCC were used respectively. Second, in regressions (5) to (8) as 
presented in table 4, NPM was used as a proxy of profitability, again; AAI, ACP, APP and CCC were regressed respectively.

The results of regression (1) detected a negative and significant relation between AAI and ROA, the coefficient of AAI (-0.029) implies that an increase of average age of inventory by 1 day is associated with a decrease on ROA by $0.029 \%$. This study has already predicted this sign which is consistent with the findings of (Deloof, 2003; Mansoori et al., 2012; Mohammad et al., 2012; Gill et al., 2010). Depending on this result hypothesis $\mathrm{H} 1-1$ is supported. The coefficients of other variables included in regression (1) are significant except for the firm's age; leverage exerts a negative and highly significant impact on ROA, while size revealed a positive and significant impact on ROA. In regression (2) a negative and significant relation was reported between ACP and ROA with a coefficient of $(-0.143)$ which implies that shortening ACP by 1 day is associated with a reduction on ROA by $0.143 \%$, accordingly hypothesis $\mathrm{H} 1-2$ is accepted. This finding is consistent with (Deloof, 2003; Lazaridis \&Tryfondis, 2006; Mohammad et al., 2012). Other coefficient in regression (2) includes size that showed a positive and significant impact on ROA, leverage that revealed a highly negative and significant impact on ROA. The results in regression (3) reported a negative and significant relation between APP and ROA; hence, H1-3 is accepted. (Deloof, 2003) justified this result by claiming that less profitable firms normally take longer time to pay its payables, leverage, size has the same significant impact as in regression (1) and (2). In regression (4) H1-4 was tested using the CCC as the comprehensive measure of WCM, the results detected a poor and negative impact of CCC on ROA. This result is consistent with (Deloof, 2003); accordingly H1-4 is rejected. In sum; the results of regressions (1) to (4) suggest that firm's management can significantly enhance the ROA by shortening the average age of inventory and average collection period.

Table 4. Regressions results for models \# (1) to (4)

\begin{tabular}{|c|c|c|c|c|}
\hline \multirow{2}{*}{$\begin{array}{l}\begin{array}{l}\text { Dependent variable: } \\
\text { Regression model }\end{array} \\
\text { Model \# }\end{array}$} & \multicolumn{4}{|c|}{$\begin{array}{l}\text { Return on assets ROA } \\
\text { Fixed effects }\end{array}$} \\
\hline & (1) & (2) & (3) & (4) \\
\hline \multirow{2}{*}{ size } & 0.165 & 0.189 & 0.191 & 0.213 \\
\hline & $(0.003)^{*}$ & $(0.003)^{*}$ & $(0.035)^{*}$ & $(0.038)^{*}$ \\
\hline \multirow{2}{*}{ leverage } & -0.167 & -0.229 & -0.632 & -0.342 \\
\hline & $(0.000)^{*}$ & $(0.000)^{*}$ & $(0.000)^{*}$ & $(0.004)^{*}$ \\
\hline \multirow{2}{*}{ age } & 0.510 & 0.483 & 0.884 & 0.655 \\
\hline & (0.611) & $(0.630)$ & (0.378) & $(0.526)$ \\
\hline AAI & $\begin{array}{c}-0.029 \\
(0.003)^{*}\end{array}$ & & & \\
\hline ACP & & $\begin{array}{c}-0.143 \\
(0.002)^{*}\end{array}$ & & \\
\hline APP & & & $\begin{array}{l}-0.290 \\
(0.001)^{*}\end{array}$ & \\
\hline $\mathrm{CCC}$ & & & & $\begin{array}{l}-0.153 \\
(0.663)\end{array}$ \\
\hline Adjusted R2 & .401 & .458 & .463 & .201 \\
\hline
\end{tabular}

Table 4 illustrates the results of regressions (5) to (8) which indicate a less significant impact of WCM on NPM. Regression (5) reported a negative and significant impact of AAI on NPM with a coefficient of ($0.524)$ and $p$-value $=(0.045)$, this result is consistent with (Abuzayed, 2011; Rehman \& Nasr, 2007, Gill et al., 2010), accordingly hypothesis H2-1 is accepted. Regression (6) and (7) confirmed a negative but weak significant impact of ACP and APP on NPM, thus, H2-2 and $\mathrm{H} 2-3$ are also supported, and however, regression (8) revealed insignificant impact of CCC on NMP. 
Table 5. Regressions results for model \# (5) to (8)

\begin{tabular}{|c|c|c|c|c|}
\hline $\begin{array}{l}\text { Dependent variable: } \\
\text { Regression model }\end{array}$ & \multicolumn{4}{|c|}{ Net profit margin (NPM) } \\
\hline model\# & (5) & (6) & (7) & (8) \\
\hline & -0.231 & 0.347 & 0.067 & 0.021 \\
\hline size & (0.817) & $(0.729)$ & $(0.974)$ & $(0.953)$ \\
\hline leverage & $\begin{array}{c}-3.372 \\
(0.001)^{*}\end{array}$ & $\begin{array}{c}-3.347 \\
(0.001)^{*}\end{array}$ & $\begin{array}{c}-3.601 \\
(0.000)^{*}\end{array}$ & $\begin{array}{c}-2.935 \\
(0.001)^{*}\end{array}$ \\
\hline age & $\begin{array}{l}-0.330 \\
(0.742)\end{array}$ & $\begin{array}{l}-0.516 \\
(0.607)\end{array}$ & $\begin{array}{c}0.680 \\
(0.498)\end{array}$ & $\begin{array}{l}-0.411 \\
(0.533)\end{array}$ \\
\hline AAI & $\begin{array}{c}-0.524 \\
(0.045)^{*}\end{array}$ & & & \\
\hline $\mathrm{ACP}$ & & $\begin{array}{c}-0.468 \\
(0.093)^{* *}\end{array}$ & & \\
\hline APP & & & $\begin{array}{c}-1.717 \\
(0.088)^{* *}\end{array}$ & \\
\hline $\mathrm{CCC}$ & & & & $\begin{array}{l}-0.725 \\
(0.352)\end{array}$ \\
\hline Adjusted R2 & 0.271 & 0.284 & 0.292 & 0.202 \\
\hline
\end{tabular}

\section{Conclusions}

The aim of this paper is to examine the impacts of working capital management on profitability. Previous studies found a negative relationship between average collection period, average age of inventory and profitability (Deloof,2003; Mansoori et al., 2012; Mohammad et al., 2012; Gill et al., 2010; Abuzayed, 2011; Rehman \& Nasr, 2007). The findings of this paper are consistent with those findings. The results of this paper suggest that managers can enhance profitability through keeping working capital components at the optimal level; managers can improve profitability by shortening the average collection period and average age of inventory to the reasonably minimum level. The results suggest that firms with poor profitability take longer time to settle their liabilities. The findings of this study can be generalized only to manufacturing firms similar to those included in this paper; future researches may employ further working capital components such as cash and securities.

\section{References}

1. Ahmad, N., \& Malik, M., \& Nadeem, M. (2014). Impact of Working Capital on Corporate Performance: A Case Study from Cement, Chemical and Engineering Sectors of Pakistan. Oman Chapter of Arabian Journal of Business and Management Review. 3. 12-22. 10.12816/0016474.

2. Alavinasab, M., \& Davoudi, E. (2013), Studying The Relationship Between Working Capital Management And Market value Of Listed Companies In Tehran Stock Exchange, Business Management Dynamics Vol.2, No.7, Pp.01-08.

3. Alqatamin, R. M. (2018). Do Family-Owned Companies Achieve High or Low Performance? Evidence from Jordan, International Journal of Academic Research in Accounting, Finance and Management Sciences, 8 (1): 215-223.

4. Altawalbeh, M. (2020). Corporate Governance Mechanisms and Firm's Performance: Evidence from Jordan. Accounting and Finance Research. 9. 11. 10.5430/afr.v9n2p11.

5. Boopathi, C., \& Leeson, J. (2016). CONCEPT OF WORKING CAPITAL MANAGEMENT. International Journal of Commerce, Business and Management 2319-2828. 5. 2319-2828.

6. Brealey, R. A., Myers, S. C., \& Allen, F. (2006), Principles of Corporate Finance. $8^{\text {th }}$ ed., Irwin McGraw-Hill Publications.

7. Deloof, M. (2003). Does working capital management affect profitability of Belgian firms?. Journal of business finance \& Accounting, 30(3-4), 573-588. 
8. Filbeck, G., and Krueger, T. (2005), "An Analysis of Working Capital Management Results Across Industries", American Journal of Business, Vol. 20 No. 2, pp. 11-20. https://doi.org/10.1108/19355181200500007.

9. Gitman, L. J. (2010). Principles of Managerial Finance, $13^{\text {th }}$ edition, printic hall, USA .

10.Kaddumi \& Ramadan. (2012) ,Working Capital Management and Firm Performance : An Analysis of Jordanian Industrial Frims , available at www.ssrn.com.

11.Kargar, J., \& Bluementhal, R. A. (1994). Leverage Impact on Working Capital in Small Businesses. TMA journal , 46-47.

12.Kasozi, J. (2017). The effect of working capital management on profitability: A case of listed manufacturing firms in South Africa. Investment Management and Financial Innovations. 14. 336-346. 10.21511/imfi.14(2-2).2017.05.

13.Lazaridis, I., \& Tryfonidis, D. (2006) Relationship between Working Capital Management and Profitability of Listed Companies in the Athens Stock Exchange. Journal of Financial Management and Analysis, Vol. 19, No. 1, Available at SSRN: https://ssrn.com/abstract=931591.

14.Malik, M., \& Jan, W., \& Ullah, K. (2012),Working Capital Management and Market value An Analysis of Firms of Textile Industry of Pakistan, Journal of Managerial Sciences Volume VI Number 2. pp.155-165.

15.Mansoori, E., Mohammad, J. (2012),The Effect of Working Capital Management on Firms Market value : Evidence Singapore, Interdisciplinary Journal of Contemporary Research in Business Vol.4,No.5, pp.472-486.

16.Malik, M., \& Bukhari, M. (2014),The Impact of Working Capital Management on Corporate Performance :A study Of Firms in Cement , Chemical and Engineering Sectors of Pakistan. Pakistan Journal of Commerce \&Social Sciences, Vol. 8(1), pp. 134-148.

17.Napompech, K. (2012), Effects of Working Capital Management on The Market value Of Thai Listed Firms, International Journal of Trade, Economics \& Finance,Vol.3,No.3,pp.227-232.

18.Nazir, M. S., \& Afza, T. (2009). Impact of Aggressive Working Capital Management Policy on Firms' Profitability. The IUP Journal of Applied Finance, 20-30.

19.Raheman, A., Nasr, M. (2007). Working capital management and profitability - case of Pakistani firms. International Review of Business Research Papers, 3: 279-300.

20.Vshnani, S., \& Shah. (2007). Impact of Working Capital Management Policies on Corporate Performance: An Empirical Study. Global Business Review, 267-281.

21.Vural, G., \& Sokmen, A., \& Cetenak, E. (2012). Effects of Working Capital Management on Firms Performance: Evidence from Turkey. International Journal of Economics and Financial Issues, Vol.2, No.4, pp.488-495. 